AL-MASHRAFIYAH: Jurnal Ekonomi, Keuangan, dan Perbankan Syariah

ISSN (p): 2597-4904 ISSN (e) : 2620-5661

Volume 3, Nomor 2, Oktober (2019), h.140-158

https://doi.org/10.24252/al-mashrafiyah.v3i2.9290

\title{
STRATEGI BAURAN PEMASARAN INDUSTRI TEMPE DALAM PERSPEKTIF EKONOMI SYARIAH DI KABUPATEN SRI INDRAPURA PROVINSI RIAU
}

\author{
Nurhadi \\ Prodi Ekonomi Islam, Sekolah Tinggi Agama Islam (STAI) Al-Azhar Pekanbaru \\ alhadijurnal@gmail.com
}

Agus Salim

Program Studi Ekonomi Syariah UIN Suska Riau

salimagus@gmail.com

Keywords:
Marketing
Mix Strategy,
Home
Industry,
Sharia
Economy.

Kata Kunci:

Strategi

Bauran

Pemasaran,

Industri

Rumahan,

Ekonomi

Syariah.

\section{ABSTRACT}

The fall in the buying and selling numbers in the tempe industry in Kec. Sabak Aub, Kab. Siak Sri Indrapura, Riau. Aims to find out the marketing mix strategy, supporting and inbibiting factors in terms of the Islamic economy of the tempe home industry. The population of 20 people is also the object. Primary data and secondary data obtained by observation, interviews, and questionnaires, then analyzed using descriptive qualitative methods. The result: 1). The marketing mix strategy undertaken by the tempe home industry is still traditional, both in terms of product, location, promotion, and price. 2). Supporting factor is one of the traditional foods, which are popular in the community and sterile from chemicals. The inbibiting factor is the limited raw material for soybeans. 3). Islamic Economics review of the Marketing Mix Strategy undertaken are: 1). Tempeh products are not probibited. 2). Prices offered are affordable. 3). Place of marketing in strategic locations and easily accessible. 4). Promotion is not yet fully in accordance with the Islamic economic system, because it has not yet maximized to increase sales, it is evident from the aspect of the strategy that it still is. Then the researcher recommends that the results of this study become a consideration for tempe industries in Riau.

$\frac{\text { ABSTRAK }}{\text { Turunnya angka jual beli dalam industri tempe di Kec. Sabak Auh, Kab. }}$ Siak Sri Indrapura, Riau. Bertujuan untuk mengetahui strategi bauran pemasaran, faktor pendukung dan penghambat ditinjau dari ekonomi Islam industri rumah tangga tempe. Populasi 20 orang juga sebagai objeknya. Data primer dan data sekunder didapat dengan observasi, wawancara, dan kuesioner, selanjutnya dianalisis dengan metode deskriptif kualitatif. Hasilnya: 1). Strategi bauran pemasaran yang dilakukan industri rumah tangga tempe masih tradisional, baik dari segi produk, tempat, promosi, dan harga. 2). Faktor pendukungnya merupakan salah satu makanan tradisional, yang populer di masyarakat dan seteril dari bahan kimia. Faktor penghambatnya, terbatasnya bahan baku kedelai. 3). Ekonomi Islam meninjau dari Strategi Bauran Pemasaran yang dilakukan adalah: 1). Produk tempe tidak dilarang. 2). Harga ditawarkan terjangkau. 3). Tempat pemasaran di lokasi strategis dan mudah diakses. 4). Promosi belum sepenuhnya sesuai dengan sistem ekonomi syariah, karena belum memaksimalkan untuk meningkatkan penjualan, terbukti dari aspek strategi masih seperti apa adanya. Maka penneliti menganjurkan agar hasil penelitian ini jadi modal pertimbangan para industri tempe di Riau. 
Nurhadi, dan Agus Salim. Strategi Bauran Pemasaran Industri...

\section{PENDAHULUAN}

Kesempurnaan Islam adalah adanya pengaturan disegala aspek kehidupan manusia, tidak hanya pada aspek spiritual saja, tetapi juga dalam hal bermuamalah yang meliputi ekonomi, sosial, politik, hukum, dan sebagainya. Firman Allah swt artinya: "Hai orang-orang yang beriman, masuklah kamu ke dalam Islam keseluruhan, dan janganlah kamu turut langkah-langkah syaitan. Sesungguhnya syaitan itu musub yang nyata bagimu”.(Q.S. Al-Baqarah: 208) (Agama, 2015).Dalil tersebut dapat dipahami bahwa perintah untuk mengamalkan ajaran Islam secara menyeluruh atau kaffah merupakan suatu kewajiban.Berkenaan dengan ajaran Islam yang bersifat komprehensip atau menyeluruh dalam buku ekonomi Islam karangan Mawardi dijelaskan bahwa Islam meliputi tiga ajaran pokok yaitu; aqidah, syariah, dan akhlaq.Syariah adalah merupakan ajaran Islam tentang hukum-hukum yang mengatur tingkah laku manusia yang telah disampaikan oleh Rasulullah saw (Mawardi, 2014).

Dari ketiga pokok ajaran tersebut diatas, salah satunya adalah akidah yang bertujuan untuk memberikan pengaruh besar terhadap pola pikir (aqliyyah), dan pola sikap (nafsiyyah) yang dilakukan, diantaranya dalam masalah ekonomi.Diantara masalah ekonomi tersebut dapat kita contohkan seperti strategi pemasaran. Strategi pemasaran adalah memilih dan menganalisa sasaran pasar yang merupakan suatu kelompok orang yang ingin dicapai oleh perusahaan atau usaha dan menciptakan suatu bauran pemasaran yang cocok dan dapat memuaskan pasar sasaran tersebut (Alma, 2014).

Secara umum, strategi bauran pemasaran dalam perspektif ekonomi Islam bukanlah merupakan suatu tindakan yang dilarang, karena tidak bertentangan dengan nash, maka hukumnya boleh. Bauran pemasaran (marketing mix) merupakan suatu kegiatan di pemasaran yang dilakukan secara terpadu. Hal ini berarti bahwa kegiatan ini dilakukan secara bersamaan antara elemen-elemen yang ada dalam bauran pemasaran (marketing mix) itu sendiri-sendiri tanpa adanya dukungan dari elemen lain.Adapun elemen-elemen yang ada dalam bauran pemasaran (marketing mix) terdiri atas produk (product), harga (price), lokasi (place), promosi (promotion), sehingga setiap elemen membutuhkan suatu strategi tesendiri. Namun tetap elemen tersebut tetap akan terkait dengan strategi pada elemen lainnya, seperti: 1). Strategi produk; 2).Strategi harga; 3). Strategi lokasi dan lay out; 4). Strategi promosi (Kasmir, 2014).

Agar suatu usaha atau bisnis yang dijalankan dapat berhasil dengan baik, alangkah baiknya perlu dilakukan sebuah strategi bersaing yang tepat. Unsur strategi persaingan tersebut adalah menentukan segmentasi pasar, menetapkan pasar sasaran, dan menentukan posisi pasar (Kasmir, 2014). Dalam strategi pemasaran ada istilah-istilah yang mendasar antara lain: 1). Kebutuhan, merupakan suatu dimana seseorang merasa kekurangan terhadap pemuas dasar tertentu atau keperluan biologis. 2). Keinginan, yaitu hasrat atau kehendak yang kuat akan pemuas kebutuhan yang sifatnya spesifik. 3). Permintaan, merupakan sebuah keinginan akan produk spesifik yang didukung oleh kemampuan dan kesediaan untuk membelinya. Serta keinginan tersebut akan menjadi permintaan jika didukung oleh daya beli (Kasmir, 2014). 4). Evaluasi, merupakan suatu usaha yang dilakukan untuk melihat sejauh mana proses pemasaran yang telah dijalankan, serta apakah ada perbaikan yang terjadi dalam usaha yang dilakukan.

Selain dari penjelasan diatas, Al-Qur'an secara tegas juga telah memberikan petunjuk kepada umat manusia untuk melakukan kegiatan pemasaran atau yang sering dikenal dengan perniagaan. Ada ayat Al-Qur'an yang menjelaskan mengenai perniagaan yang artinya: 'Hai orang-orang yang beriman, sukakah kamu aku tunjukkan suatu perniagaan yang dapat menyelamatkanmu dari azab yang pedih? (yaitu) kamu beriman kepada Allah dan RasulNya dan berjihad di jalan Allah dengan harta dan jiwamu. Itulah yang lebih baik bagimu, jika kamu mengetabui. (Qs. As-Saf : 1011)(Agama, 2015). Maka ayat ini menjadi dasar dalam berniaga dan tentunya didalam berniaga ada pemasaran dengan barang yang di niagakan.

Adapun makna kata tijarah dari ayat tersebut diatasmemiliki dua makna, yaitu: pertama, perniagaan secara umum yang mencakup perniagaan antara manusia dengan Allah. Ketika 
seseorang memilih petunjuk dari Allah dan Rasul-Nya, berjuang dijalan-Nya, dengan harta dan jiwa, membaca kitab Allah, mendirikan Shalat, menafkahkan sebagian rezekinya, maka itulah sebaik-baik perniagaan antara manusia dengan Allah swt (Yunia, 2013). Hal tersebut di karenakan kemuliaan manusia itu tergantung kepada apa yang dilakukannya. Dengan itu, sesuatu amalan atau pekerjaan yang mendekatkan seseorang kepada Allah adalah sangat penting serta patut untuk diberi perhatian (Susanto, 2013).

Sedangkan makna tijarah yang kedua adalah perniagaan secara khusus, yang berarti pemasaran atau pun jual beli antar manusia (Yunia, 2013). Sehingga dalam melaksanakan aktifitas perdagangannya, Rasulullah Saw telah mencontohkan kepada umatnya dengan sangat baik tentang penerapan strategi pemasaran yang jitu dan tepat sasaran, mengingat kondisi daerahnya yang dikelilingi oleh padang pasir yang panas dan kering (Jusmaliani, 2014).

Secara umum, strategi bauran pemasaran selayaknya tidak hanya digunakan oleh perusahaan-perusahaan besar saja. Namun, hendaknya bagi para pengusaha bome industri juga harus menggunakan strategi bauran pemasaran.Berkenaan dengan adanya bome industri yang ada di dalam suatu negara maka ia akan mampu meningkatan pendapatan perkapita suatu Negara. Syarief Hasan juga mengatakan agar sebuah negara maju dan sejahtera minimal harus memiliki $2 \%$ wirausaha dari total penduduknya. Dengan jumlah penduduk Indonesia yang mencapai 237 Juta jiwa, dibutuhkan wirausaha minimal 4,7 juta. Kenyataannya saat ini baru 592 ribu wirausaha di Indonesia atau 0,24\% (Hasan, 2018).

Dewasa ini, home industri yang ada di Indonesia mulai bermunculan dan beraneka ragam jenisnya. Hal tersebut dapat kita contohkan seperti industri pembuatan roti, industri kerajinan rotan, industri pengrajin kerupuk ubi, dan industri pengusaha tempe. Berkenaan dalam pemasaran produk tempe, dapat kita berikan contoh pemasaran tempe yang ada di kecamatan Sabak Auh Kabupaten Siak Sri Indrapura Riau. Kebanyakan dari mereka para pembuat tempe dari segi pemasaran ia hanya memasarkan tempenya dipasar tradisional yang ada disekitarnya saja.

Berdasarkan wawancara yang dilakukan kepada beberapa pengusaha pembuat tempe yaitu Bapak Rohmat, beliau mengeluhkan menurunnya daya beli pelanggan/konsumen dikarenakan adanya pedagang yang masuk dari luar daerah kecamatan Sabak Auh yang berani menjual produk tempenya dibawah rata-rata harga pasar (Rahmat, 2018).

Disamping itu, dari wawancara yang penulis lakukan kepada pengusaha tempe mereka mengeluhkan harga beli kacang kedelai yang kian naik. Dari harga yang awalnya berkisar Rp. 7.200/Kg;- kini harga tersebut naik menjadi Rp. 9.000/Kg. kenaikan tersebut akan mempengaruhi produksi yang mulai tidak menentu karena kesulitan dalam membeli bahan baku. Mengingat jumlah permintaan masyarakat akan produk tempe yang kian meningkat.

Berdasarkan latar belakang diatas maka permasalahan yang dibahas dalam penelitian ini dapat dirumuskan sebagai berikut:Bagaimana strategi bauran pemasaran (marketing mix) pada home industri tempe, apa faktor pendukung dan penghambat dalam pengembangan strategi bauran pemasaran, serta bagaimana tinjauan Ekonomi Islam terhadap bauran pemasaran (marketing mix) yang dilakukan pada home industri tempe di Kecamatan Sabak Auh Kabupaten Siak Sri Indrapura Riau?

\section{LANDASAN TEORI}

\section{Terminologi Strategi}

Suatu perusahaan dipastikan memiliki manajemen tersendiri. Diantara fungsi manajemen adalah planning atau strategi.Setiap perusahaan membutuhkan strategi untuk terus berkembang. Perumusan strategi harus dilakukan dengan tepat diawal akan mendirikan sebuah perusahaan. Suatu perusahaan dapat mengembangkan strategi untuk mengatasi ancaman 
Nurhadi, dan Agus Salim. Strategi Bauran Pemasaran Industri...

eksternal dan merebut peluang yang ada. Proses perumusan strategi dan evaluasi yang dilakukan dalam strategi disebut perencanaan strategis(Yulianti, dkk, 2008). Strategi merupakan alat untuk mencapai tujuan.

Pengertian strategi menurut beberapa ahli antara lain; 1). Menurut A.Halim, Strategi merupakan suatu cara dimana sebuah lembaga atau organisasi akan mencapai tujuannya sesuai peluang dan ancaman lingkungan eksternal yang dihadapi serta kemampuan internal dan sumber daya. Menurut Syafrizal strategi ialah cara untuk mencapai sebuah tujuan berdasarkan analisa terhadap faktor eksternal dan internal. 2). Menurut Chandler, strategi merupakan alat untuk mencapai tujuan perusahaan dalam kaitannya dengan tujuan jangka panjang, program tindak lanjut, serta prioritas alokasi sumber daya (Rangkuti, 2015). 3). Menurut Learned, Christenses, Andrews, dan Guth merumuskan bahwa strategi adalah alat untuk menciptakan keunggulan bersaing. Dengan demikian salah satu fokus strategi adalah memutuskan apakah bisnis tersebut harus ada atau tidak ada (Suryatama, 2016). 4). Menurut Porter, strategi merupakan alat yang sangat penting untuk mencapai keunggulan bersaing (Porter, 2001).

Dapat disimpulkan bahwa strategi merupakan hal yang sangat penting dilakukan oleh perusahaan untuk mencapai keunggulan baik dalam mengatasi persaingan atau dalam mendapatkan konsumen sehingga kesuksesan suatu perusahaan dapat tercapai.Karena suatu perusahaan dikatakan berhasil apabila tujuan utamanya tercapai.Sementara itu, secara konseptual strategi dapat dipahami sebagai suatu garis besar haluan dalam bertindak untuk mencapai sasaran yang telah ditentukan. Strategi juga bisa dipahami sebagai segala cara dan daya untuk menghadapi sasaran tertentu dalam kondisi tertentu agar memperoleh hasil yang diharapkan secara maksimal (Arifin, 2010).

Menurut Suryana, beliau mengemukakan 5P yang memiliki arti sama dengan strategi, yaitu (Suryana, 2009): a. Strategi adalah perencanaan (plan) Konsep pemasaran tidak terlepas dari aspek perencanaan, arahan atau acuan gerak langkah perusahaan untuk mencapai suatu tujuan di masa depan. Akan tetapi, tidak selamanya strategi adalah perencanaan ke masa depan yang belum dilaksanakan. Strategi juga menyangkut segala sesuatu yang telah dilakukan di masa lampau, misalnya pola-pola perilaku bisnis yang telah dilakukan di masa lampau. b. Strategi adalah pola (patern) Strategi yang belum terlaksana dan berorientasi ke masa depan atau intended strategy dan disebut realized strategy karena telah dilakukan oleh perusahaan. c. Strategi adalah posisi (position) Menempatkan produk tertentu ke pasar tertentu yang dituju. Strategi ini cenderung melihat ke bawah, yaitu ke satu titik bidik dimana produk tertentu bertemu dengan pelanggan, dan melihat ke luar, yaitu meninjau berbagai aspek lingkungan eksternal. d. Strategi adalah perspektif (perspektive) Dalam strategi ini lebih ke dalam perspektif melihat ke dalam, yaitu ke organisasi tersebut. e. Strategi adalah permainan (play) (Suryana, 2009).

Strategi sebagai suatu maneuver tertentu untuk memperdaya lawan atau pesaing. Keberhasilan perusahaan dalam pemasaran dipengaruhi oleh persaingan pasar (Rozi, 2017).. Oleh karena itu, perusahaan perlu mengenali siapa pesaingnya, apa sasaran dan strategi mereka, apa kekuatan dan kelemahan mereka dan bagaimana pola reaksi mereka dalam menghapi persaingannya. Sehingga dengan mengetahui semua itu, maka perusahaan akan mampu menerapkan strategi bagaimana yang akan diterapkan dan sesuai dengan kebutuhan perusahaan serta kebutuhan pasar pada saat itu (Suryana, 2009).

Profesor Philip Kotler mendefinisikan: "marketing is a societal process by which individuals and groups obtain what they need and want through creating, offering, and exchanging products and services of value freely with others (Kotler, 2011). Sedangkan ruang lingkupnya The Scope of Marketing masih menurut Kotler, meliputi hal-hal "marketing people are involved in marketing 10 types of entities: goods, services, experiences, events, persons, places, properties, organizations, information, and ideas (Kotler, 2011).

Sedangkan definisi marketing menurut World Marketing Association (WMA) yang diajukan oleh Hermawan Kartajaya dan sudah dipresentasikan di World Marketing Conference di Tokyo pada April 1998 adalah: "Marketing adalah sebuah disiplin bisnis strategis yang 
mengarahkan proses penciptaan, penawaran, dan perubahan value dari satu inisiator kepada stakeholder-nya (Kartajaya, 2012).

Dengan demikian, maka syariah marketing adalah sebuah disiplin bisnis strategis yang mengarahkan proses penciptaan, penawaran, dan perubahan value dari suatu inisiator kepada stakeholder-nya, yang dalam keseluruhan prosesnya sesuai dengan akad-akad dan prinsipprinsip muamalah (bisnis) dalam Islam (Luntajo, 2019).

Kata "syariah" (al-syari'ah) itu sendiri telah ada dalam bahasa Arab sebelum turunnya AlQuran. Kata yang semakna dengannya juga ada dalam Taurat dan Injil. Kata syari'at dalam bahasa Ibrani disebutkan sebanyak 200 kali, yang selalu mengisyaratkan pada makna "kehendak Tuhan yang diwahyukan sebagai wujud kekuasaan-Nya atas segala perbuatan manusia (Ghani, 2015).

Dalam Al-Quran kata syari'ah disebutkan hanya sekali dalam Surah Al-Jatsiyah, "Kemudian Kami Jadikan kamu berada didalam suatu syariat (peraturan) dari urusan (agama) itu, maka ikutilah syariat itu dan janganlah kamu mengikuti hawa nafsu orang-orang yang tidak mengetahui" (QS Al-Jatsiyah: 18) (Luntajo, 2019).

Kemudian kata itu muncul dalam bentuk kata kerja (fi'il) dan derivatnya (turunannya) sebagai berikut: "Dia telah mensyariatkan bagi kamu tentang agama apa yang telah diwasiatkan_Nya kepada Nuh dan apa yang telah Kami wahyukan kepadamu, dan apa yang telah kami wasiatkan kepada Ibrahim, Musa dan Isa..." (QS Al-Syuura: 13) (Luntajo, 2019).

Apakah mereka mempunyai sembahan-sembahan selain Allah yang mensyariatkan untuk mereka agama yang tidak diizinkan Allah? Sekiranya tak ada ketetapan yang menetukan (dari Alllah), tentulah mereka telah dibinasakan. Dan sesunggguhnya orang-orang yang zalim itu akan memperoleh azab yang amat pedih" (QS. Al-Syuura: 21) (Luntajo, 2019).

Kata syariah berasal dari kata syara'a al-syai'a yang berarti 'menerangkan' atau 'menjelaskan sesuatu'. Atau berasal dari kata syir'ah dan syari'ah yang berarti 'suatu tempat yang dijadikan sarana untuk mengambil air secara langsung sehingga orang yang mengambilnya tidak memerlukan bantuan alat lain (Ma'luf, T.th).

Syaikh Al-Qardhawi mengatakan (Al-Qardhawi, 1990): "Cakupan dari pengertian syariah menurut pandangan Islam sangatlah luas dan komprehensif (al-syumul). Didalamnya mengandung makna mengatur seluruh aspek kehidupan, mulai dari aspek ibadah (hubungan manusia dengan Tuhannya), aspek keluarga (seperti nikah, talak, nafkah, wasiat, warisan), aspek bisnis (perdagangan, industri, perbankan, asuransi, utang-piutang, pemasaran, hibah), aspek ekonomi (permodalan, zakat, bait al-mal, fa'i, ghanimah), aspek hukum dan peradilan, aspek undang-undang hingga hubungan antar Negara (Luntajo, 2019).

Karena marketing berhubungan erat dengan bisnis atau perdagangan, maka marketing adalah bentuk muamalah yang dibenarkan dalam Islam, sepanjang dalam segala proses transaksinya terpelihara dari hal-hal terlarang oleh ketentuan syariah. Maka, syariah marketing adalah sebuah disiplin bisnis strategis yang mengarahkan proses penciptaan, penawaran dan perubahan value dari suatu inisiator kepada stakeholders-nya, yang dalam keseluruhan prosesnya sesuai dengan akad dan prinsip-prinsip muamalah (bisnis) dalam Islam (Luntajo, 2019).

Artinya bahwa dalam syariah marketing, seluruh proses, baik proses penciptaan, proses penawaran, maupun proses perubahan nilai (value), tidak boleh ada hal-hal yang bertentangan dengan akad dan prinsip-prinsip muamalah yang Islami. Sepanjang hal tersebut dapat dijamin, dan penyimoangan prinsip-prinsip muamalah islami tidak terjadi dalam suatu transaksi apapun dalam pemasaran dapat dibolehkan (Luntajo, 2019).

Ada 4 karakteristik syariah marketing menurut Kartajaya dan Sula (Kartajaya, dan Sula, 2016) yang dapat menjadi panduan bagi para marketers sebagai berikut: 1). Teistis (rabbaniyyah): jiwa seorang syariah marketer meyakini bahwa hukum-hukum syariat yang teistis atau bersifat ketuhanan ini adalah yang paling adil, paling sempurna, paling selaras 
Nurhadi, dan Agus Salim. Strategi Bauran Pemasaran Industri...

dengan segala bentuk kebaikan, paling dapat mencegah segala bentuk kerusakan, paling mampu mewujudkan kebenaran, memusnahkan kebatilan dan menyebarluaskan kemaslahatan. 2). Etis (akhlaqiyyah): Keistimewaan lain dari syariah marketer selain karena teistis (rabbaniyyah) juga karena ia sangat mengedepankan masalah akhlak (moral, etika) dalam seluruh aspek kegiatannya, karena nilai-nilai moral dan etika adalah nilai yang bersifat universalo, yang diajarkan oleh semua agama. 3). Realistis (al-waqi'iyyah) : syariah marketer adalah konsep pemasaran yang fleksibel, sebagaimana keluasan dan keluwesan syariah islamiyah yang melandasinya. Syariah marketer adalah para pemasar professional dengan penampilan yang bersih, rapid an bersahaja, apapun model atau gaya berpakaian yang dikenakannya, bekerja dengan mengedepankan nilai-nilai religius, kesalehan, aspek moral dan kejujuran dalan segala aktivitas pemasarannya. 4). Humanistis (insaniyyah): keistimewaan syariah marketer yang lain adalah sifatnya yang humanistis universal, yaitu bahwa syariah diciptakan untuk manusia agar derajatnya terangkat, sifat kemanusiaannya terjaga dan terpelihara, serta sifat-sifat kehewanannya dapat terkekang dengan panduan syariah. Syariat islam diciptakan untuk manusia sesuai dengan kapasitasnya tanpa menghiraukan ras, warna kulit, kebangsaan dan status.Hal inilah yang membuat syariah memiliki sifat universal sehingga menjadi syariah humanistis universal (Luntajo, 2019).

\section{Definisi Pemasaran}

Pemasaran menurut Philip Kotler yaitu adalah suatu proses sosial dan manajerial dengan nama perorangan atau kelompok memperoleh yang mereka butuhkan dan inginkan melalui pembuatan dan pertukaran produk serta nilai dengan pihak lain(Philip Kotler, 2008; Astriyani, 2016).

\section{Pengertian Bauran}

Bauran Pemasaran merupakan campuran dari variabel-variabel pemasaran yang dapat dikendalikan yang digunakan oleh suatu perusahaan untuk mengejar tingkat penjualan yang diinginkan dalam pasar sasaran(Philip Kotler, 2008; Astriyani, 2016).

Bauran pemasaran yang terdiri dari 4P yaitu : Product (Produk), Price (Harga), Promotion (Promosi), Place (Tempat/Distribusi). Instrumen tersebut merupakan faktor pendukung dalam pemasaran yang dirancang perusahaan untuk mengimplementasikan pemasaran produk kepada target pasar sasaran (Latifah, 2007). Menurut Mcdaniel, Lamb, Hair (2005). Istilah bauran pemasaran mengacu pada paduan strategi produk, distribusi, promosi, dan penentuan harga yang bersifatounik dirancang untuk menghasilkan pertukaran yang saling memuaskan dengan pasar yangodituju (Winars dan Al-Farisyi, 2015).

Strategi bauran pemasaran perlu diimplementasikan dengan baik, baik dengan cara mengikuti budaya setiap sasaran pasar atau memakai budaya asli perusahaan, melakukan inovasi untuk keunggulanoproduk dalam pasar, distribusi yang baik disetiap pasar dalam mencari pelanggan, mengamati setiap politik dan ekonomi disuatu negara dalam menetapkan strategi, menyesuaikan harga produk, tergantung dari setiap perusahaan dalam mengimplementasikan strategi tersebut (Perdana, 2016).

\section{METODE PENELITIAN}

Lokasi penelitian di Kecamatan Sabak Auh Kabupaten Siak Sri Indrapura Riau. Selanjutnya, penelitian ini dilakukan kepada para pengusaha tempe yang ada dilokasi tersebut. Subyek penelitian para pengusaha tempe yang ada di Kecamatan Sabak Auh Kabupaten Siak Sri Indrapura Riau. Sedangkan Obyek penelitian, strategi bauran pemasaran (marketing mix) pada home industritempe di Kecamatan Sabak Auh Kabupaten Siak Sri Indrapura Riau menurut ekonomi Islam. Populasi merupakan jumlah keseluruhan unit analisis, yaitu objek yang akan 
diteliti, sampel adalah suatu bagian dari populasi (Soehartono, 2014). Populasi dan sampel penelitian, seluruh pengusaha tempe yang berjumlah 20 orang.

Data primer merupakan data yang diperoleh langsung dari para pengusaha bome industri tempe yang ada di Kecamatan Sabak Auh dan juga merupakan data yang belum tersedia dan untuk memperoleh data tersebut peneliti harus menggunakan beberapa instrumen penelitian seperti kuesioner, wawancara, observasi dan sebagainya, maka data tersebut dinamakan data primer (Tanjung, el. 2013). Data Sekunder yaitu data yang diperoleh dari sumber kedua atau sumber sekunder dari data yang kita butuhkan (Burhan, 2015), yaitu dari leteratur yang berkaitan dengan penelitian ini. Dengan metode pengumpulan datadengan Observasi, angket danWawancara.

Analisa yang digunakan dalam penelitian ini adalah analisa Deskriptif Kualitatif, data kualitatif berasal dari observasi, wawancara dan angket yang dijelaskan dengan cara menghubungkan antara satu fakta dengan fakta yang lainnya kemudian data itu dianalisa untuk diambil kesimpulan. Dalam menyusun data yang diperoleh dengan tiga metode sabagai berikut: 1). Deduktif, mengumpulkan data-data umum kemudian di analisis dan diuraikan secara khusus. 2). Induktif, mengumpulkan data-data khusus dan kemudian dianalisis lalu diuraikan secara umum. 3). Deskriptif, yaitu menggambarkan permasalahan secara tepat kemudian di analisa sesuai data yang diperoleh.

\section{HASIL DAN PEMBAHASAN}

Strategi Bauran pemasaran (Marketing Mix) adalah kombinasi dari variabel atau kegiatan yang merupakan inti dari sistem pemasaran (Sunarsih dan HMS, 2015). Hal ini berarti, bauran pemasaran merupakan kumpulan-kumpulan variabel-variabel yang dapat digunakan perusahaan untuk mempengaruhi tanggapan konsumen (Abidin, 2012). Sehingga dengan adanya variable-variabel yang digunakan perusahaan maka akan menciptakan suatu kombinasi yang memberikan hasil maksimal (Alma, 2010). Sedangkan menurut Kotler bauran pemasaran adalah kelompok kiat pemasaran untuk mencapai sasaran pemasaran. Kiat pemasaran tersebut adalah: Produk (Product), Promosi (Promotion), Harga (Price), saluran distribusi atau tempat (Place)(Sunyoto, 2013). Selanjutnya, dari hasil penelitian yang dilakukan oleh penulis, terdapat daftar nama-nama para pengrajin home industritempe yang ada di Kecamatan Sabak Auh Kabupaten Siak Sri Indrapura Riau sebanyak 20 Orang. Lihat tabel berikut:

Tabel 1: Dafar Nama Pengrajin Home Industri Tempe di Kecamatan Sabak Auh Riau

\begin{tabular}{rlccl}
\hline No & \multicolumn{1}{c}{ Nama } & Jenis Kelamin & Umur & \multicolumn{1}{c}{ Tempat Tinggal } \\
\hline 1. & Mustofa & Laki-Laki & 38 Tahun & Desa Bandar Sungai \\
\hline 2. & Paniyem & Perempuan & 38 Tahun & Kampung Sungai Tengah \\
\hline 3. & Yati & Perempuan & 39 Tahun & Desa Sabak Permai \\
\hline 4. & Bagus & Laki-Laki & 40 Tahun & Desa Bandar Sungai \\
\hline 5. & Piyah & Perempuan & 45 Tahun & Desa Laksamana \\
\hline 6. & Tumirah & Perempuan & 45 Tahun & Desa Laksamana \\
\hline 7. & Rahmad & Laki-Laki & 45 Tahun & Kampung Sungai Tengah \\
\hline 8. & Mujiyati & Perempuan & 46 Tahun & Kampung Sungai Tengah \\
\hline 9. & Maslahah & Perempuan & 47 Tahun & Desa Bandar Sungai \\
\hline 10. & Soemah & Perempuan & 47 Tahun & Kampung Sungai Tengah \\
\hline 11. & Moblong & Laki-Laki & 50 Tahun & Desa Laksamana \\
\hline
\end{tabular}


Nurhadi, dan Agus Salim. Strategi Bauran Pemasaran Industri...

\begin{tabular}{clcll}
\hline No & \multicolumn{1}{c}{ Nama } & Jenis Kelamin & Umur & \multicolumn{1}{c}{ Tempat Tinggal } \\
\hline 12. & Mesinem & Perempuan & 56 Tahun & Kampung Sungai Tengah \\
\hline 13. & Tukimun & Laki-Laki & 60Tahun & Kampung Sungai Tengah \\
\hline 14. & Selamet & Laki-Laki & 60 Tahun & Kampung Sungai Tengah \\
\hline 15. & Yahmen & Laki-Laki & 60 Tahun & Kampung Sungai Tengah \\
\hline 16. & Tukiman & Laki-Laki & 60 Tahun & Desa Bandar Sungai \\
\hline 17. & Boningan & Laki-Laki & 63 Tahun & Desa Laksamana \\
\hline 18. & Mbah Siten & Perempuan & 63Tahun & Desa Bandar Sungai \\
\hline 19. & Tukinem & Perempuan & 65 Tahun & Kampung Sungai Tengah \\
\hline 20. & Mbah Woni & Laki-Laki & 65 Tahun & Desa Laksamana \\
\hline
\end{tabular}

Sumber: Data primer setelah diolah, Tahun 2015

Dapat kita lihat dari Tabel tersebut bahwa di Kecamatan Sabak Auh terdapat 20 orang pengrajin home industri tempe. Selanjutnya dari 20 orang yang ada di Kecamatan Sabak Auh tersebut terbagi menjadi beberapa desa atau kampung yang berkecimpung dalam pengrajin bome industri tempe antara lain: Kampung Sungai Tengah terdapat 20 orang pengrajin home industri tempe, Desa Sabak Permai terdapat 1 orang pengrajin tempe, Desa Laksamana terdapat 5 orang pengrajin home industri tempe, dan sedangkan pengrajin bome industri tempe yang ada di desa Bandar Sungai terdapat 5 orang.

Sementara itu, dari wawancara yang dilakukan penulis kepada salah satu pengusaha home industri tempe yang ada di Desa Laksamana yaitu bapak Boningan, beliau mengungkapkan bahwa ia menekuni home industri tempe sejak tahun 1980 sampai sekarang (Boningan, 2018).Kemudian,dengan menggunakan metode angket, wawancara, serta studi kepustakaan, unsur-unsur terpenting yang ada pada strategi bauran pemasaran (marketing mix) pada home industri tempe yang ada Di Kecamatan Sabak Auh, adalah sebagai berikut:

\section{Strategi Produk (Product)}

Produk merupakan sesuatu yang ditawarkan pada suatu pasar untuk mendapatkan perhatian dari konsumen untuk dimiliki, digunakan maupun dikonsumsi serta bisa memuaskan keiinginan atau kebutuhan konsumen (Rina dan Yuriadi, 2019). Untuk jangka pendek, strategi produk baru didesain untuk mempengaruhi konsumen agar mau mencoba produk, sedangkan untuk jangka panjang, strategi produk didesain untuk mengembangkan loyalitas merek dan mendapatkan pangsa pasar yang besar (Riva'I, 2012).

Adapun faktor-faktor yang terkandung dalam suatu produk adalah mutu/kualitas, penampilan (features), pilihan yang ada (options), gaya (styles), merek (brand names), pengemasan (packing), ukuran (sizes), jenis (product line), macam (product item), jaminan (warranties), dan pelayanan (services).Sementara itu, dari data yang diperoleh dari angket yang disebarkan kepada para responden berkenaan dengan pengadaan bahan baku pembuat tempe yaitu kedelai, akan di jelaskan pada Tabel berikut ini:

Tabel 2: Pengadaan Bahan Baku Pembuat Tempe di Kecamatan Sabak Auh Riau

\begin{tabular}{cccc}
\hline No & Tanggapan & Jumlah Pembuat Tempe(Orang) & Presentase (\%) \\
\hline 1 & Mudah untuk didapat & 20 & $100 \%$ \\
\hline 2 & Tidak Mudah didapat & 0 & - \\
\hline & Jumlah & $\mathbf{2 0}$ Orang & $\mathbf{1 0 0 \%}$ \\
\hline
\end{tabular}

Sumber: Data primer setelah diolah, Tahun 2015 
AL-MASHRAFIYAH: Jurnal Ekonomi, Keuangan, dan Perbankan Syariah Volume 3, Nomor 2, Oktober 2019

Tabel 3: Tanggapan Responden Berkenaan dengan Bahan Baku Kedelai untuk Pembuatan Produk Tempe di Kecamatan Sabak Auh Riau

\begin{tabular}{cccc}
\hline No & Tanggapan & Jumlah Pembuat Tempe(Orang) & Presentase (\%) \\
\hline 1 & Bahan kedelai lokal & - & - \\
\hline 2 & Bahan kedelai impor & 20 & $100 \%$ \\
\hline & Jumlah & $\mathbf{2 0}$ & $\mathbf{1 0 0 \%}$ \\
\hline
\end{tabular}

Sumber: Data primer setelah diolah, Tahun 2015

Berdasarkan Tabel di atas, diketahui bahwa mayoritas 20 orang responden atau sebesar $100 \%$ pengusaha home industri tempe, mendapatkan bahan baku, karena bahan baku yang digunakan dijual ditoko-toko yang ada di Kecamatan Sabak Auh dan sekitarnya.Berkenaan dengan bahan baku kacang kedelai yang digunakan oleh pengusaha home industri tempe hal ini dapat diketahui dari hasil angket yang penulis sebarkan kepada responden, sehingga diolah Seperti yang ada pada Tabel 3.

Dari Tabel 3 di atas apat kita ketahui bahwa dari keseluruhan responden yang berjumlah 20 orang dengan persentase $100 \%$ menyatakan bahwa dalam membuat produk tempenya masih menggunakan bahan baku kedelai impor yang berasal dari Negara Malaysia, hal ini sangat disayangkan karena bila dalam membuat produk tempenya menggunakan kedelai lokal maka hasil dari produk tempenya tidak bagus, dan hasil tempe yang dibuat pun cepat busuk.Selanjutnya untuk mengetahui tanggapan responden tentang jenis atau variasi produk tempe dapat dilihat pada Tabel 4.

Tabel 4: Tanggapan Responden Tentang Jenis atau Variasi Produk Home Industri Tempe di Kecamatan Sabak Auh Riau

\begin{tabular}{cccc}
\hline No & Tanggapan & Jumlah Pembuat Tempe(Orang) & Presentase (\%) \\
\hline 1 & 1 (Satu) Jenis/ Variasi & 5 & $25 \%$ \\
\hline 2 & 2 (Dua) Jenis/ Variasi & 11 & $55 \%$ \\
\hline 3 & 3 (Tiga) Jenis/ Variasi & 4 & $20 \%$ \\
\hline 4 & Lebih 3 Jenis/ Variasi & - & - \\
\hline & Jumlah & $\mathbf{2 0}$ & $\mathbf{1 0 0 \%}$ \\
\hline
\end{tabular}

Sumber: Data primer setelah diolah, Tahun 2015

Berdasarkan Tabel 4 di atas, dapat kita lihat bahwa mengenai tanggapan responden tentang jenis atau variasi produk tempe yang di buat oleh para pembuat tempe dimana ada 5 orang atau 25\% membuat produk tempenya dalam 1 jenis/variasi, 11 orang atau 55\% membuat produk tempenya dalam 2 jenis/variasi, sedangkan 4 orang atau $20 \%$ dalam membuat produk tempenya dalam 3 jenis/variasi.

Adapun dalam penelitian yang penulis lakukan, para pengusaha bome industritempe membuat produk tempenya terbagi kedalam beberapa jenis yaitu: tempe balok, tempe yang dikemas dalam bungkus plastik, tempe yang di bungkus daun pisang, dan tempe khusus untuk membuat kripik. Sehingga diantara beberapa jenis produk tempe yang dibuat oleh para pengusaha home industri tempe tersebut jenis produk tempe yang lebih diminati oleh para konsumen adalah produk tempe yang dikemas daun pisang.Selain variasi atau jenis yang dibuat oleh para pengusaha bome industri tempe, berikut akan dijelaskan melalui Tabel 5 mengenai idealnya ketahanan produk tempe yang dipasarkan kepada konsumen: 
Nurhadi, dan Agus Salim. Strategi Bauran Pemasaran Industri...

Tabel 5: Tanggapan Responden Tentang Lama Idealnya Ketahanan Produk Tempe di Kecamatan Sabak Auh Riau

\begin{tabular}{cccc}
\hline \multirow{2}{*}{ No } & Tanggapan & $\begin{array}{c}\text { Jumlah Pembuat Tempe } \\
\text { (Orang) }\end{array}$ & Presentase (\%) \\
\hline 1 & 1 Hari & - & - \\
\hline 2 & 2 Hari & - & - \\
\hline 3 & 3 Hari & 20 & $100 \%$ \\
\hline \multicolumn{2}{c}{ Jumlah } & $\mathbf{2 0}$ & $\mathbf{1 0 0 \%}$ \\
\hline
\end{tabular}

Sumber: Data primer setelah diolah, Tahun 2015

Berdasarkan Tabel 5 di atas dapat dilihat bahwa mengenai lama idealnya ketahanan produk tempe yang diproduksi oleh para pengusaha home industritempe semua responden mennyatakan bahwa idealnya mampu bertahan selama 3 hari.

\section{Strategi Harga (Price)}

Sesesuai dengan pembahasan yang telah disinggung pada bab sebelumnya, bahwa harga Menurut Tjiptono, Secara sederhana istilah harga dapat diartikan sebagai jumlah uang (Satuan Moneter) dan/ atau aspek lain (Non Satuan Moneter) yang mengandung utilitas atau kegunaan tertentu yang diperlukan untuk mendapatkan suatu produk (Tjiptono, dkk, 2012). Menurut Chandra dalam Tjiptono dikatakan bahwa harga merupakan pernyataan nilai dari suatu produk (a statement of value)(Tjiptono, dkk, 2012). Sedangkan menurut Wijaya, harga adalah apa yang dibayar seseorang untuk apa yang diperolehnya dan nilainya dinyatakan dalam mata uang (Tjiptono, dkk, 2012).

Selanjutnya penentuan harga merupakan salah satu aspek penting dalam kegiatan pemasaran (Hurriyati, 2010). Harga menjadi sangat penting untuk diperhatikan, mengingat harga sangat menentukan laku tidaknya produk atau jasa suatu produk. Salah dalam menentukan harga akan berakibat fatal terhadap produk yang ditawarkan nantinya (Sukristono, 2012).

Berkenaan dengan penentuan harga, para pengusaha bome industri tempe yang ada di Kecamatan Sabak Auh dalam menjual produk tempenya mereka menghadapi suatu kendala yaitu dalam menjual produk tempenya ke konnsumen, mayoritas para pengusaha bome industri tempe mereka tidak melakukan adanya kesepakatan harga dalam memasarkan produk tempenya antara satu penjual dengan penjual yang lain. Hal ini dapat kita lihat penjelasannya pada tabel berikut ini:

Tabel 6: Tanggapan Responden Mengenai Ada atau Tidaknya Kesepakan Harga antara Penjual yang Satu dengan yang Lainnya di Kecamatan Sabak Auh Riau

\begin{tabular}{cccc}
\hline No & Tanggapan & Jumlah Pembuat Tempe(Orang) & Presentase (\%) \\
\hline 1 & Ada kesepakatan harga & - & - \\
\hline 2 & Tidak ada kesepakatan & 20 & $100 \%$ \\
\hline & Jumlah & $\mathbf{2 0}$ & $\mathbf{1 0 0 \%}$ \\
\hline
\end{tabular}

Sumber: Data primer setelah diolah, Tahun 2015

Dari Tabel 6 yang ada di atas, dapat kita lihat bahwa dari keseluruhan orang responden yang berjumlah 20 dengan persentase 100\% menyatakan bahwa mereka tidak menggunakan kesepakan harga antara satu penjual tempe dengan penjual tempe yang lain.Disamping itu pada kenyataannya, setiap konsumen memiliki kecenderungan untuk membeli suatu barang bilamana barang yang ditawarkan tersebut tepat serta layak karena harga yang ditetapkan suatu perusahaan itu sendiri maupun terhadap perekonomian secara keseluruhan.Selanjutnya untuk mengetahui tanggapan responden tentang harga tempe per bungkus yang dijual kepada para konsumen dapat kita lihat pada Tabel 7. 
Tabel 7: Tanggapan Responden terhadap Harga Per Bungkus Tempe yang dijual Kepada Konsumen di Kecamatan Sabak Auh Riau

\begin{tabular}{cccc}
\hline No & Tanggapan & Jumlah Pembuat Tempe(Orang) & Presentase (\%) \\
\hline 1 & Rp. 1.000/Bungkus & 16 & $80 \%$ \\
\hline 2 & Rp. 2.000/Bungkus & 4 & $20 \%$ \\
\hline 3 & Rp. 3.000/Bungkus & - & - \\
\hline & Jumlah & $\mathbf{2 0}$ & $\mathbf{1 0 0 \%}$ \\
\hline
\end{tabular}

Sumber: Data primer setelah diolah, Tahun 2015

Dari Tabel 7 di atas dapat kita ketahui bahwa 16 orang atau $80 \%$ pengusaha home industri tempe menjual produk tempenya dengan harga Rp. 1.000/Bungkus, sedangkan 4 orang atau $20 \%$ pengusaha home industri tempe menjual produk tempenya seharga Rp.2.000/Bungkus. Dengan demikian, adapun produk tempe yang banyak diminati oleh para konsumen adalah harga tempe yang dijual oleh para pengusaha home industri tempe dengan harga Rp. 1.000 /Bungkus.

\section{Strategi Distribusi atau Tempat (Place)}

Produk industri place diartikan sebagai saluaran distribusi, sedangkan untuk produksi jasa place diartikan sebagai tempat pelayanan jasa (Hurriyati, 2015). Disisi lain, pada situasi perekonomian saat ini produsen tidak langsung menjual hasil produksinya kepada konsumen (Abbas, 2015). Namun, dalam mengembangkan pangsa pasar, produsen banyak melalui tahapan perantara untuk memasarkan hasil produksinya.Beberapa perantara seperti pedagang besar dan pengecer yang membeli dan menjual kembali barang dagangannya disebut pedagang perantara (Rismiati, 2012). Berkenaan dengan distribusi atau tempat (place) yang mudah di jangkau oleh konsumen untuk membeli produktempe, maka akan dijelaskan pada tabel berikut ini:

Tabel 8: Tanggapan Responden tempat yang mudah dijangkau \& lebih banyak dikunjungi Konsumen untuk Membeli Produk Tempe di Kecamatan Sabak Auh Riau

\begin{tabular}{cccc}
\hline No & Tanggapan & Jumlah Pembuat Tempe(Orang) & Presentase (\%) \\
\hline 1 & Warung/Toko & 6 & $30 \%$ \\
\hline 2 & Di Pasar & 14 & $70 \%$ \\
\hline & Jumlah & $\mathbf{2 0}$ & $\mathbf{1 0 0 \%}$ \\
\hline
\end{tabular}

Sumber: Data primer setelah diolah, Tahun 2015

Dari Tabel 8 di atas, dapat kita ketahui bahwa dari 20 orang responden menyatakan bahwa 6 orang responden atau 30\% memberi tanggapan bahwa tempat yang mudah untuk dijangkau serta yang sering dikunjungi oleh konsumen untuk membeli produk tempe yaitu di warung, sedangkan 14 orang responden atau $70 \%$ menyatakan bahwa tempat yang sering dikunjungi oleh konsumen guna untuk membeli produk tempe yaitu di pasar.

Kemudian berkaitan dengan adanya tempat yang mudah untuk dijangkau oleh konsumen, seorang pengusaha home industritempe bila ia akan menjual produk tempenya di warung/toko maka ia menitipkan produk tempenya dibeberapa tempat. berikut akan dijelaskan berapa tempat sasaran produsen guna untuk menitipkan produk tempenya, lihat Tabel 9 . 
Nurhadi, dan Agus Salim. Strategi Bauran Pemasaran Industri...

Tabel IX: Tanggapan Responden berkenaan dengan berapa tempat yang digunakan untuk menjual Produk Tempenya di Kecamatan Sabak Auh Riau

\begin{tabular}{cccc}
\hline No & Tanggapan & Jumlah Pembuat Tempe(Orang) & Presentase (\%) \\
\hline 1 & 1 (Satu) Tempat & 3 & $15 \%$ \\
\hline 2 & 2 (Dua) Tempat & 10 & $50 \%$ \\
\hline 3 & 3 (Tiga) Tempat & 1 & $5 \%$ \\
\hline 4 & $\begin{array}{l}\text { Lebih dari 3 (Tiga) } \\
\text { Tempat }\end{array}$ & 6 & $30 \%$ \\
\hline & Jumlah & $\mathbf{2 0}$ & $\mathbf{1 0 0 \%}$ \\
\hline
\end{tabular}

Sumber: Data primer setelah diolah, Tahun 2015

Pada Tabel 9 di atas, diketahui bahwa dari 20 orang responden, dimana 3 orang responden atau 15\% menyatakan bahwa ia menitipkan produk tempenya hanya 1 (satu) tempat, sementara 10 orang responden dengan presentase $50 \%$ menyatakan bahwa ia menitipkan produk tempenya di 2 (Dua) tempat, 1 orang responden atau 5\% menyatakan bahwa ia menitipkan produk tempenya di 3 (Tiga) tempat. Sedangkan 6 orang dengan presentase 30\% menyatakan bahwa ia menitipkan produk tempenya lebih dari 3 (tiga) tempat. Dengan demikian, bila konsumen ingin membeli produk tempe, maka seorang konsumen tidak perlu mendatangi home industri tempe secara langsung. Akan tetapi bila konsumen ingin membeli produk tempe, maka konsumen dapat membelinya di warung-warung atau kedai harian. Hal ini senada dengan observasi yang dilakukan oleh penulis disalah satu kedai harian yang terletak di Kampung Sungai Tengah, dengan nama kedai "Abu Jaya" (Abu Jaya, 2018).Selanjutnya, untuk mengetahui tanggapan responden mengenai berapakali rata-rata para pengusaha bome industritempe dalam memasarkan produk tempenya, dapat kita lihat pada Tabel 10.

Tabel X: Tanggapan Responden berkenaan dengan berapa kali Pengusaha Home Industri Tempe Memasarkan Produk Tempenya di Kecamatan Sabak Auh Riau

\begin{tabular}{cccc}
\hline No & Tanggapan & Jumlah Pembuat Tempe (Orang) & Presentase (\%) \\
\hline 1 & 1 Kali dalam seminggu & 2 & $10 \%$ \\
\hline 2 & 2 Kali dalam seminggu & 12 & $60 \%$ \\
\hline 3 & 3 Kali dalam seminggu & 3 & $15 \%$ \\
\hline \multirow{2}{*}{4} & $\begin{array}{l}\text { Lebih dari 3 kali dalam } \\
\text { seminggu }\end{array}$ & 3 & $15 \%$ \\
\hline & Jumlah & $\mathbf{2 0}$ & $\mathbf{1 0 0 \%}$ \\
\hline
\end{tabular}

Sumber: Data primer setelah diolah, Tahun 2015

Dari Tabel 10 di atas, dapat kita sama-sama pahami bahwa dari 20 orang responden, 2 Orang dengan persentase $10 \%$ menjawab dalam pemasaran produk tempenya di pasarkan sebanyak 1 kali dalam seminggu, 12 orang dengan persentase $60 \%$ menyatakan bahwa dalam pemasarnnya dilaksanakan sebanyak 2 kali dalam seminggu, 3 orang dengan persentase $15 \%$ menyatakan dalam memasarkan produk tempenya dilakukan sebanyak 3 kali dalam seminggu, sedangkan 3 orang lainnya dengan persentase 15\% menyatakan bahwa dalam menjual produk tempenya dilakukan lebih dari 3 kali dalam seminggu.

\section{Strategi Promosi (Promotion)}

Menurut William J. Stanton, adalah unsur dalam bauran pemasaran perusahaan yang didayagunakan untuk memberitahukan, membujuk, dan mengingatkan, tentang produk perusahaan (Sunyoto, 2013; Diniaty dan Agusrinal, 2014). Berkaitan dengan kegiatan promosi, 
pada tabel berikut ini akan dijelaskan bagaimana strategi promosi yang dilakukan oleh para pengusaha bome industri tempe dalam promosikan produk tempenya:

Tabel 11: Tanggapan Responden berkaitan dengan Strategi untuk Menarik Daya Beli Produk Tempe kepada Konsumen di Kecamatan Sabak Auh Riau

\begin{tabular}{clcc}
\hline No & \multicolumn{1}{c}{ Tanggapan } & $\begin{array}{c}\text { Jumlah Pembuat Tempe } \\
\text { (Orang) }\end{array}$ & Presentase (\%) \\
\hline 1 & $\begin{array}{l}\text { Memberikan discount harga per } \\
\text { bungkus kepada konsumen }\end{array}$ & - & - \\
\hline 2 & $\begin{array}{l}\text { Bila membeli dalam jumlah banyak, } \\
\text { maka harga lebih murah }\end{array}$ & 20 & $100 \%$ \\
\hline & Jumlah & $\mathbf{2 0}$ & $\mathbf{1 0 0 \%}$ \\
\hline
\end{tabular}

Sumber: Data primer setelah diolah, Tahun 2015

Dari Tabel di atas, dapat kita simpulkan bahwa keseluruhan responden yang berjumlah 20 orang dengan presentase $100 \%$ menyatakan bahwa dalam menarik pelanggan strategi promosi yang digunakannya ialah bila konsumen membeli pproduk tempe dalam jumlah banyak, maka harga yang diberikan kepada para pengusaha home industri tempe harganya lebih murah. Sehingga dapat disimpulkan bahwa Strategi bauran pemasaran (marketing mix) yang dilakukan oleh para pengusaha home industritempe masih dengan cara tradisional tanpa ada pengembangan pemasaran, baik dari segi produk (product), tempat (place), promosi (promotion), dan harga (price).

Namun, Allah SWT. Memerintahkan kepada orang yang beriman untuk memperhatikan apa yang telah diperbuatnya untuk hari esok yaitu sesuai dengan firman-Nya, yang artinya: "Hai orang-orang yang beriman, bertakwalah kepada Allah dan bendaklah setiap diri memperhatikan apa yang telah diperbuatnya untuk hari esok (akbirat); dan bertakwalah kepada Allah, sesunggubnya Allah Maha Mengetabui apa yang kamu kerjakan. (Qs. Al-Hasyr : 18).

\section{Faktor Pendukung Dan Penghambat}

Masalah atau hambatan merupakan bagian bagi kehidupan. Keberhasilan serta kemajuan suatu usaha yang dijalankan oleh seseorang melalui berbagai tantangan hidup dengan perjuangan serta pengorbanan sekecil apapun membuat seseorang bisa menghargai kehidupan itu sendiri apalagi bila dilakukan pada saat yang tepat dan diberikan denan hati yang tulus serta ikhlas (Mardhian dan Sudarsana, 2016). Selanjutnya, berbicara faktor pendukung Adapun faktor pendukung bagi para pengusaha home industri tempe dalam memasarkan produk tempenya kepada konsumen antara lain adalah: 1). Tempe merupakan salah satu makanan tradisional tanpa bahan pengawet yang kaya protein dan mengandung banyak gizi serta di sukai oleh masyarakat di Kecamatan Sabak Auh dan Sekitarnya (Boningan, 2018). 2). Tempe merupakan salah satu makanan yang digemari orang-orang, baik dari kalangan bawah maupun golongan orang atas atau kaya. 3). Tempe yang telah diproduksi oleh pegusaha bome industri tempe dapat mampu bertahan selama 3 hari. Jadi jika produk tempe tidak terjual habis dalam satu hari tidak masalah jika dijual besoknya lagi (Bagus, 2018). 4). Tempe merupakan salah satu makanan yang diproduksi tidak perlu menggunakan alat teknologi serta harga tempe pun terjangkau oleh masyarakat dari harga yang terendah yaitu Rp. 1000 s.d 2000 perbungkus (Rahmad, 2018).

Sedangkan faktor-faktor penghambat dalam memasarkan produk tempe diantaranyaadalah: 1). Mengenai bahan baku utama yang digunakan untuk membuat tempe adalah kacang kedelai. Hal tersebut yang dirisaukan oleh salah satu pengusaha tempe bila pasokan kedelai dari malaysia tidak ada atau tiba-tiba harga kedelai meningkat karena harga 
Nurhadi, dan Agus Salim. Strategi Bauran Pemasaran Industri...

BBM naik, maka harga kedelai pun akan ikut melambung tinggi. Maka, jumlah penjualan produk tempe untungnya tidak sebanding dengan harga kedelai (Mujiyati, 2018). 2). Modal merupakan salah satu hal terpenting dalam menjalankan sebuah usaha, karena tanpa adanya modal, jalan perputaran roda sebuah usaha yang dijalankan tidak akan berjalan dengan normal. Dengan kata lain, para pengusaha tempe kekurangan modal dalam pengurusan surat izin usaha dari pemerintah. Karena dalam pengurusan tersebut pasti memerlukan dana yang cukup besar dalam prosesnya (Mustofa, 2018). 3). Pengetahuan Tentang Pemasaran. Home industritempe merupakan salah satu kegiatan usaha yang mengolah bahan baku kacang kedelai menjadi sebuah makanan yang bebas dari bahan pengawet serta bahan yang berbahaya yang tidak baik untuk dikonsumsi.

Adapun dalam pemasarannya, rata-rata para pengusaha bome industritempe dalam memasarkan produk tempenya hanya dijual dipasar sekitarnya saja.Selain itu dalam penjualan produk tempenya, mayoritas para pengusaha home industritempe dalam menjual produk tempenya hanya dijual titipkan di warung-warung yang ada disekitar desa atau yang dekat dengan home idustri pembuat tempe. Berikut dapat kita lihat penjelasan yang berkenaan dengan strategi pemasaran produk tempenya pada tabel berikut ini (Tumirah, 2018).

Tabel 12: Tanggapan Responden berkenaan dengan Strategi Pengusaha Home Industri Tempe dalam Memasarkan Produk Tempenya ke Konsumen di Kecamatan Sabak Auh Riau

\begin{tabular}{cccc}
\hline No & Tanggapan & Jumlah Pembuat Tempe(Orang) & Presentase (\%) \\
\hline 1 & Dititipkan di warung & 9 & $45 \%$ \\
\hline 2 & Dijual kepasar & 11 & $55 \%$ \\
\hline & Jumlah & $\mathbf{2 0}$ & $\mathbf{1 0 0 \%}$ \\
\hline
\end{tabular}

Sumber: Data primer setelah diolah, Tahun 2015

Dari Tabel di atas dapat kita ketahui bersama bahwa dari 20 orang responden 9 orang dengan persentase $45 \%$ dalam strategi pemasaran produk tempe yang siap untuk dijual kekonsumen, mereka menjualnya dengan cara menitipkan produk tempenya di warungwarung. Kemudian 11 orang responden lainnya dengan presentase 55\% dalam memasarkan produk tempenya dengan cara menjualnya langsung kepasar. Hal tersebut sangat disayangkan, karena dalam pemasaranya para pengusaha home industritempe hanya menjualnya di warungwarung dan di pasar yang ada di Kecamatan Sabak Auh. Bila produk tempe tersebut dijual diluar kecamatan Sabak Auh maka ia akan menambah income atau pendapatan yang sangat menggiurkan bagi para pengusaha home industri tempe yang ada di Kecamatan Sabak Auh.

\section{Tinjauan Ekonomi Syariah terhadap Bauran Pemasaran (Marketing Mix)}

Dalam pandangan agama Islam, pencapaian prestasi duniawi bukanlah hal yang terlarang.Bahkan sepanjang kemakmuran digunakan untuk beramal maka hal itu sangat dianjurkan.Seseorang yang hidup dalam keadaan kecukupan berpeluang lebih besar untukmembelanjakan hartanya dijalan Allah dengan harapan untuk memperoleh pahala (Gumira, el., 2014). Selanjutnya, dalam melakukan analisis dari strategi bauran pemasaran (Marketing Mix) padahome industri tempe yang ada di Kecamatan Sabak Auh Riau, dapat dianalisis dari empat aspek, sebagai berikut: 1). Produk (Product). Menurut adiwarman karim, ada beberapa penyebab perbuatan atau benda menjadi terlarang, yaitu (1) haram zatnya, (2) haram selain dzatnya, dan (3) haram akadnya (Warman, 2013). Dari beberapa penyebab perbuatan diatas, maka dalam pembuatan produk tempe tidak terdapat indkasi larangan atau keharaman dari produk yang di hasilkan oleh bome industri tempe.

Hal tersebut sesuai dengan firman Allah swt surat An-Nahl: 114, yang artinya: "Maka makanlah yang halal lagi baik dari rezeki yang telah diberikan Allah kepadamu; dan syukurilah nikmat Allah, jika kamu banya kepada-Nya saja menyembab”.'( Q.s: An-Nahl: 114). 2). Harga (Price). Untuk 
mengetahui pandangan ekonomi syariah mengenai harga yang termasuk indikator dari strategi pemasaran, dimana dapat dilihat dari harga yang ditetapkan kepada konsumen, sehingga harga terjangkau. Adapun harga produk tempe yang ditawarkan kepada konsumen yaitu dengan harga Rp. 1.000; sampai dengan Rp. 2.000; Dalam hal ini tidak ada larangan dalam ekonomi syariah mengenai tinggi rendahnya harga yang ditetapkan oleh suatu produk.

Rasulullah saw bersabda yang artinya: "Anas Ibnu Malik berkata: pada zaman Rasulullah saw pernah terjadi kenaikan harga barang-barang di Madinah. Maka orang-orang berkata: Wahai Rasulullah, harga barang-barang melonjak tinggi, tentukanlah harga bagi kami. Lalu Rasulullah saw bersabda: "Sesunggubnya Allablah penentu harga, Dialah yang menahan, melepas, dan pemberi rizkei. Dan aku berharap menemui Allah dan berharap tiada seorangpun yang menuntutku karena kasus penganiayaan terhadap darah manpun harta benda." (H.R. Abu Daud) (Abu Daud, t.th). 3).

Tempat (Place). Dari data yang diperoleh dari penelitian yang dilakukan penulis di Kecamatan Sabak Auh Riau berkaitan dengan tempat (place), sehingga dapat dianalisis menurut Ekonomi Syariah, dimana home industri tempe yang ada di Kecamatan Sabak Auh Riau sudah sesuai dengan hukum kausalitas yang harus diperhatikan. Dimana, home industritempe yang ada di kecamatan Sabak Auh Riau dalam memasarkan produknya mengutamakan lokasi atau tempat (place) yang strategis dan mudah dijangkau oleh konsumen. 4). Promosi (Promotion). Adapun dilihat dari aspek promosi yang meupakan indikator dari strategi pemasaran, para pegusaha home industritempe dalam mempromosikan produknya tidak bertentangan dengan prinsip Islam. Disisi lain dari data yang diperoleh diketahui bahwa home industritempe yang ada di Kecamatan Sabak Auh kurang optimal terhadap promosi yang dilakukan. Hal ini bukan pengaruh dari promosi yang sekarang mereka lakukan, akan tetapi merupakan hasil dari usaha yang dilakukan oleh generasi mereka terdahulu. Oleh karena itu, sudah menjadi hal yang logis untuk saat sekarang ini bahwa home industri tempe yang ada di Kecamatan Sabak Auh tidak maksimal dan optimal dalam kegiatan promosi. Jika dilihat pada penelitian sebelumya, maka dari aspek produk, harga, distribusi, promosi masih relative berbeda, karena sudah sedikit mengalami perbaikan, sehingga diharapkan kedepannya industri tempe ini bisa bersaing dengan industri lainya.

\section{KESIMPULAN}

Setelah melakukan penelitian baik itu dari hasil angket yang di berikan kepada para pengusaha home industritempe serta wawancara, dengan para pengusaha home industri tempe, kemudian pengamatan langsung dari obyek penelitian maka penulis dapat menyimpulkan beberapa hal sebagai berikut: 1). Strategi bauran pemasaran (marketing mix) yang dilakukan oleh para pengusaha home industritempe masih dengan cara tradisional tanpa ada pengembangan pemasaran, baik dari segi produk (product), tempat (place), promosi (promotion), dan harga (price). 2). Faktor pendukung dari adanya home industritempe yang ada di Kecamatan Sabak Auh Riau adalah tempe merupakan salah satu makanan tradisional yang bebas dari zat kimia, tanpa bahan pengawet dan merupakan salah satu makanan yang kaya akan protein serta mengandung banyak gizi yang dapat tahan hingga 3 hari. Selanjutnya, tempe merupakan makanan tradisional yang disukai oleh orang dari kalangan bawah serta kalangan atas, dan dari cara pembuatannyapun tidak menggunakan alat tekhnologi yang canggih/modern. Sedangkan faktor penghambatnya adalah terbatasnya ketersediaan bahan baku kedelai, karena bahan baku yang digunakan adalah kedelai impor dari Malaysia, hambatan lain yang dihadapi oleh para pengusaha home industri tempe adalah modal yang digunakan untuk pengembangan usaha bome industri tempe, serta tidak adanya pengetahuan tentang pemasaran yang dimiliki oleh para pengusaha homeindustri tempe yang ada di Kecamatan Sabak Auh Kabupaten Siak Sri Indrapura Riau. 3). Strategi bauran pemasaran (marketing mix) yang dijalankan oleh para pengusaha home industri tempe yang ada di Kecamatan Sabak Auh dapat disimpulkan bahwa dari produk yang 
Nurhadi, dan Agus Salim. Strategi Bauran Pemasaran Industri...

di hasilkan oleh home industri tempe di Kecamatan Sabak Auh Riau tidak adanya indikasi larangan atau keharaman. Selanjutnya dari segi harga produk yang ditawarkan kepada konsumen dapat dijangkau oleh konsumen. Pada aspek tempat atau distribusi yang dilakukan oleh para pengusaha home industri tempe yang ada di Kecamatan Sabak Auh Riau dalam memasarkan produknya lebih mengutamakan lokasi atau tempat yang strategis dan mudah dijangkau oleh konsumen. Kemudian dari segi promosi yang dilakukan oleh para pengusaha tempe yang ada di Kecamatan Sabak Auh Riaubelum sepenuhnya sesuai dengan sistem ekonomi syariah, karena mereka tidak maksimal dalam berupaya untuk meningkatkan penjualan produksinya, hal ini terbukti bahwa dari aspek strategi masih apa adanya, sedangkan Islam menganjurkan umatnya untuk selalu berupaya mencapai yang terbaik bukan apa adanya.

\section{DAFTAR PUSTAKA}

Abbas, Firdayanti. 2015. "Pengaruh Marketing Mix Terhadap Kepuasan Konsumen (Pada Home Industry Moshimoshi Cake Samarinda)". eJournal Administrasi Bisnis, Volume 3, Nomor 1, 244-258.

Abdullah, Thamrin \& francis tantri. 2012. Manajemen Pemasaran, Jakarta: PT. Raja Grafindo Persada.

Abidin, Zainal Mohd. 2012. Manajemen pemasaran, Kuala Lumpur: Dewan Bahasa.

Agama, Kementerian RI. 2015. Al-Qur'an dan Terjemaban. Semarang: Toha Putra.

Alma, Buchari. 2012. Pengantar Bisnis, Bandung: Alfabeta.

Alma, Buchari. 2014. Kewirausahaan, Bandung: Alfabeta.

Al-Qardhawi, Yusuf. 1990. Madkhal Li Dirasah Al-Syariah Al-Islamiyyah. Kairo: Maktabah.

An-Nabhani, Taqiyuddin. 2014. Sistem Ekonomi Islam (Terj), Hafidz Abdurrahman, Jakarta: HTI Press.

Assauri, Sofjan. 2014. Manajemen Pemasaran (Dasar, Konsep dan Strategi), Jakarta: PT. Graf Grafindo Persada.

Astriyani, Fitri. 2016. Penerapan Strategi Bauran Pemasaran (Marketing Mix) Produk Gula Semut Berbasis Agribisnis Perspektif Ekonomi Islam (Studi Kasus Koperasi Nira Perwira Candinata, Kutasari, Purbalingga), Program Studi Ekonomi Syariah Fakultas Ekonomi dan Bisnis Islam Institut Agama Islam Negeri Purwokerto.

Bagus 2015. Pemilik Rumah Industri Tempe, Wawancara, 23 Mei

Boningan. 2015. Pemilik Rumah Industri Tempe, Wawancara, 21 Mei

Bungin, M. Burhan. 2015. Metodologi Penelitian Kuantitatif. Jakarta: PT. Grup Media Kencana Prenada.

Cravens, David W. t.th. Pemasaran Strategis. Jakarta: PT. Gelora Sastra Utama.

David, Abu. t.th. Sunan Abu Daud. Bairut: Dar Al-Kitab Al Arrobi.

Diniaty, Dewi dan Agusrinal. 2014. "Perancangan Strategi Pemasaran Pada Produk Anyaman Pandan (Studi Kasus: Home Industry Saiyo Sakato Di Kenagarian Padang Laweh 
AL-MASHRAFIYAH: Jurnal Ekonomi, Keuangan, dan Perbankan Syariah Volume 3, Nomor 2, Oktober 2019

Kecamatan Koto Vii Kabupaten Sawahlunto Sijunjung)". Jurnal Sains, Teknologi dan Industri, Vol. 11, No. 2, 175-184.

Ghani, Muhammad Abdul. 2015. The Spirituality in Business. Jakarta: Pena Pundi Aksara.

Hakim, Lukman. (2012). Prinsip Ekonomi Islam, Jakarta: PT.Gelora Aksara Pratama.

Harahap, Sofyan S. 2011. Etika Bisnis dalam Perspektif Ekonomi Islam. Jakarta: Salemba Empat.

Hurriyati, Ratih. 2010. "Penerapan Model Strategi Pemasaran Usaha Kecil Berbasis Web 2.0 Sebagai Upaya Dalam Meningkatkan Daya Saing Industri Kecil”. Program Studi Pendidikan Manajemen Bisnis Fakultas Pendidikan Ekonomi Dan Bisnis Universitas Pendidikan Indonesia, 1-25.

Ratih. 2015. Pemasaran Konsumen \& Campuran Loyalitas. Bandung: Alfabeta

Ika, Fauzia, Yunia. 2013. Etika Bisnis dalam Islam. Jakarta: Grup Media Kencana Prenada.

Irawan. 2012. Manajemen Pemasaran Modern, Yogyakarta: Prenada Media Group.

Jakfar. 2013. Studi Kelayakan Bisnis, Jakarta: PT. Grup Media Kencana Prenada.

Jusmaliani. 2014. Bisnis Berbasis Syariah. Jakarta: Bumi Aksara.

Karim, Adi Warman A. 2013. Yurisprudensi Bank Islam dan analisis kenangan. Jakarta: Raja Grafindo Persada.

Kasmir. 2014. Manajemen Biaya, Jakarta: PT. Raja Grafindo Persada.

Kata, E. Gumira, Yayuk Eka Pratiwi. 2013. Agribisnis Syariah, Manajemen Agribisnis dalam Perspektif Syariah Islam, Jakarta: Menyebarkan Swadaya.

Kertajaya, Hermawan \& Muhammad Syakir Sula. 2016. Pemasaran Syariah, Bandung: PT. Mizan.

Hermawan, et al. 2012. MarkPlus On Strategy. Jakarta: PT Gramedia Pustaka Utama.

Kartajaya, Hermawan dan Sula, Muhammad Syakir. 2016. Syariah Marketing. Bandung : Mizan.

Kotler, Philip. 2010. Dasar-Dasar Pemasaran, Jakarta: Inter Media.

Kotler, Philip. 2010. Pemasaran, Jakarta: Erlangga.

Kotler, Philip. 2011. Marketing Management Millenium Edition. Tenth Edition. New Jersey: Prentice-Hall Inc.

Kotler, Philip. 2010. Pemasaran, Jakarta: PT. Akademi Sastra.

Kotler, Philip. 2008. Manajemen Pemasaran, terj. Jaka Wasana, Jakarta: PT. Gelora Aksara Pratama.

Lamb, Hair, McDaniel. (2005). Pemasaran Buku 1. Jakarta: Penerbit Salemba Empat.

Latifah, Sri Wahjuni. 2007. "Penerapan Sistem Pemasaran Terpadu dan Sistem Informasi Akuntansi Pada Sentra Industri Pengolahan Berbasis Kedelai". Jurnal Dedikasi, Volume $4,1-11$. 
Nurhadi, dan Agus Salim. Strategi Bauran Pemasaran Industri...

Luntajo, Moh. Muzwir R. 2019. Dasar Filosofi Marketing Syariah. https://media.neliti.com/media/publications/240338-dasar-filosofi-marketingsyariah-b2a0c125.pdf, diakse 13 September 2019.

M. Arifin. 2010. Psikologi Suatu Pengantar. Jakarta: PT Bumi Aksara.

Mardhian, Tria Ayu dan Sudarsana. 2016. "Strategi Keberlangsungan Usaha Industri Kripik Tempe (Studi Deskriptif Kualitatif Pengrajin Kripik Tempe di Desa Karangtengah Prandon Kecamatan Ngawi Kabupaten Ngawi Provinsi Jawa Timur)'. Jurnal Sosiologi Dilema, Vol. 31, No. 1, 67-77.

Ma'luf, Luis. T.th. Mu’jam Alfaz̧h Al-Quran Al-Karim. Kairo: Majma’ Al-Lughah Al-'Arabiyyah.

Marius, Angiopora P. 2010. Dasar-Dasar Pemasaran, Jakarta: PT. Raja Grafindo

Mawardi. 2014. Ekonomi Islam, Pekanbaru: Alaf Riau Graha UNRI Press

Mujiyati. 2018. Pemilik Rumah Industri Tempe, Wawancara, 23 Mei

Mursid, M. 2013. Manajemen Pemasaran, Jakarta: Bumi Literacy.

Mustofa. 2015. Pemilik Rumab Industri Tempe, Wawancara, 23 Mei

Nitisemito, Alex. S. 2010. Pemasaran, Jakarta: Ghalia Indonesia.

Perdana, Yongki, Putra Zainul Arifin M. Kholid Mawardi. 2016. Analisis.Strategi,Bauran Pemasaran,Dalamlmeningkatkan Volume.Ekspor (Studi,Pada,Bali Pasadena,Rattan), Jurnal Administrasi Bisnis (JAB)|Vol. 39 No.1 Oktober.

Porter, Michael. 2001. Strategi Bersaing Teknik Menganalisis Industri dan Pesaing, Erlangga: Jakarta.

Rahmad. 2015. Pemilik Rumah Industri Tempe, Wawancara, 15 Mei

Rangkuti, Freddy. 2015. Analisis SWOT : Teknik Membedah Kasus Bisnis, Kompas Gramedia: Jakarta.

Rina, Nofha dan Yuriadi, Ruri Wahyu. 2019. "Strategi Komunikasi Pemasaran Dalam Mempertahankan Brand Image Brownies Amanda Sebagai Kue Oleh-Oleh Bandung". Jurnal Lingkar Studi Komunikasi, Vol. 5 No. 1, 66-73.

Rismiati, Catur E. 2011. Pemasaran Barang dan Jasa, Yogyakarta: kanisius.

Riva'i, Veithzal. 2012. Pemasaran Islam (Membangun dan Mengembangkan Bisnis dengan Praktek Pemasaran dari Rasulullah), Jakarta: PT. Gramedia Persada Utama.

Rozi, Akhmad Fahrur. 2017. "Analisis Strategi Pemasaran Pada Djawa Batik Solo Analysis Marketing Strategies On Djawa Batik Solo". Jurnal Manajemen Dan Bisnis Indonesia, Vol. 3 No. 2, 173-186.

Salim, Agus. 1436H / 2015M. Strategi Bauran Pemasaran di Home Industri Tempe di Kecamatan Sabak Auh, Kabupaten Siak Sri Indrapura, Ditinjau Menurut Ekonomi Islam. Departemen Ekonomi Islam, Fakultas Syariah dan Hukum, Universitas Islam Negeri, Sultan Syarif Kasim Riau.

Soehartono, Irwan. 2014. Metode Penelitian Sosial, Bandung: PT. Remaja Rosdakarya. 
AL-MASHRAFIYAH: Jurnal Ekonomi, Keuangan, dan Perbankan Syariah Volume 3, Nomor 2, Oktober 2019

Stanton, William J. 2011. Prinsip Pemasaran, Jakarta: Erlangga.

Sukirno, Sadono, dkk. 2012) Pengantar Bisnis, Jakarta: Kencana.

Sunarsih, Lilik dan HMS, Umar. 2015. "Strategi Pemasaran Home Industry Pengrajin Anyaman Bambu Di Desa Gintangan Kecamatan Rogojampi Kabupaten Banyuwangi". Jurnal Pendidikan Ekonomi, Edisi IX No. 2, 57-68.

Sunyoto, Danang. 2013. Perilaku Konsumen Panduan Penelitian Sederhana untuk Mengenali Konsumen), Yogyakarta: CAPS.

Suryana. 2009. Kewirausahaan, Jakarta: Salemba Empat Patria.

Suryatama, Erwin. 2016. Lebih Memahami Analisis SWOT Dalam Bisnis, Kata Pena: Surabaya.

Susanto, Teguh. 2013. Muhammad. SAW Sang Billionaire, Yogyakarta: Buku Pintar.

Sutirman. 2015. Strategi Pemasaran, Artikel diakses pada 6 April 2015 dari http://tirman.wordpress.com/strategi-pemasaran/.

Swastha, Basu DH. 2010. Aqas-Azas Marketing, Jakarta: Idhiil.

Syarief, Hasan. 2015. Indonesia membutubkan 4,1 juta pengusaha baru, 15 Februari 2015 m.tempo.co/read/news/2011/12/14/089371713/ Indonesia- Need-41-JutaPengusaha-Baru.

T. Handoko. 2010. Manajemen Pemasaran, Yogyakarta: BPFE.

Tanjung, Hendri \& Abrista Devi. 2013. Metodologi Penelitian Ekonomi Islam, Jakarta: Gramata Publishing.

Tjiptono, Fandy. Et al. 2012. Strategi Pemasaran, Andi Yogyakarta, Yogyakarta: Andi Yogyakarta.

Tumirah. 2015. Pemilik Rumah Industri Tempe, Wawancara, 23 Mei

W. Boyd. 2010. Manajemen Pemasaran (Pendekatan Strategis Dengan Orientasi Global), Jakarta: Erlangga.

Winars, Kukuh dan Al-Farisyi, Imam. 2015. "Pengukuran Kinerja Marketing Mix Dan Perumusan Srategi Pemasaran Ukm Batik Pamekasan (Studi Kasus: UKM Batik Kec. Proppo Kab. Pamekasan)". Jurnal Ekonomi dan Bisnis Tabun XXVI, No. 3, 246-255.

Yulianti, Muliana., Mudikdjo, Kooswardhono dan Sarma, Ma'mun. 2008. "Kajian Strategi dan Bauran Pemasaran Batik Garutan (Studi Kasus : Perusahaan Batik Tulis Garutan RM, Garut, Jawa Barat)". Jurnal MPI, Vol. 3 No. 1., 11-24. 